KRYSTYNA DATA

ORCID: 0000-0002-4442-7570

Akademia Ignatianum w Krakowie

\title{
Perswazja w prozie Jana Kochanowskiego
}

Czym charakteryzowała się szesnastowieczna perswazja i jak tworzył się jej językowy obraz? Niniejszy artykuł jest próbą odpowiedzi na te pytania, jego podstawą materiałową są utwory Jana Kochanowskiego pisane prozą.

W dorobku literackim największego polskiego poety, Jana z Czarnolasu, obok znakomitej poezji są też utwory prozatorskie. Jego dorobek poetycki jest jednak nieporównywalnie większy niż prozatorski, dlatego też większość rozpraw, opracowań i artykułów dotyczy różnorodnych aspektów jego poezji — od analiz i interpretacji historyczno-literackich, poprzez stylistyczne, do językowych. Nic w tym dziwnego skoro tekstów pisanych prozą jest zaledwie kilka: Wzór pań mężnych, Wróżki, O Czechu i Lechu historyja naganiona, Wykład cnoty, İ pijaństwo jest rzecz sprosna a nieprzystojna człowiekowi, Przy pogrzebie rzecz, Apoftegmata, Ortografija polska oraz dwa listy do J. Zamojskiego i jeden do S. Fogelwedera ${ }^{1}$. Wszystkie te utwory ukazały się dopiero po śmierci poety. Może to świadczyć o tym, że sam poeta traktował prozę jako coś gorszego i nie przywiązywał wagi do tych tekstów ${ }^{2}$. Dlaczego żaden $z$ tekstów pisanych prozą nie został wydany za życia poety, nie wiemy. Być może część z nich to teksty przeznaczone tylko do wygłoszenia, czy poeta gdzieś je wygłosił — nie wiadomo. Sprawom druku swoich dzieł Kochanowski dopiero pod koniec życia zaczął poświęcać więcej uwagi, niewiele utworów ukazało się przed rokiem 1578 (Ziomek 1973: 324). Część dorobku pozostała w rękopisie do śmierci poety w 1584 roku. Wydawca Kochanowskiego, Jan Januszowski, postanowił wydać pośmiertnie prozatorskie utwory, doceniając ich wartość. W przedmowie do historii $O$ Czechu

1 Podstawą analizy są teksty zamieszczone w wydaniu sejmowym dzieł Kochanowskiego, w t. VII Proza. W dalszej części artykułu stosuję skróty tytułów przytaczanych utworów: Wróżki$\mathrm{Wr}$, O Czechu i Lechu historyja naganiona - Czech, Wyklad cnoty - Cn, Iż pijaństwo jest rzecz sprosna a nieprzystojna czlowiekowi - Pij, Przy pogrzebie rzecz — Pog, Apoftegmata - Ap.

${ }^{2}$ Niektóre $\mathrm{z}$ omawianych zagadnień przedstawiam także w artykule o cechach mówioności i oralności występujących w tekstach poety - zarówno prozatorskich, jak i poetyckich. Zob. Data 2015. 
i Lechu, zwracając się do siostrzeńca poety, Adama Dzierżanowskiego, kanonika warszawskiego, pisze:

jest temu coś blisko czterech lat M.(ości) X.(ięże) żem [...] Jana Kochanowskiego, poety polskiego, rzeczy pisanych po części był między ludzi wydał. Teraz, iż się jeszcze cokolwiek fragment jego zebrało, jako namniejsza rzecz jego godna świata i piastowania ludzkiego, tak to, cokolwiek jest, bez grzechu zakryć by człowiek nie mógł. [...] Ale mówiąc o panu Kochanowskim, ponieważ rzeczy jego ręku mych doszły, ile mi czas i curta suppellex domestica dopuszcza, jedne teraz wydaję, drugie też niedługo, da Bóg, wydam (Kochanowski 1997: 194, 197).

Dzięki Januszowskiemu możemy poznać wielkiego poetę polskiego renesansu także jako autora tekstów prozatorskich i aktywnego uczestnika życia publicznego. Teksty te reprezentują różne typy wypowiedzi: jest to proza fabularna, refleksyjno-moralistyczna i naukowa.

Prozatorska twórczość Kochanowskiego jest niedoceniana i rzadko jest przedmiotem badań. Większość badaczy literatury renesansu wyraża się krytycznie o stylu prozy Kochanowskiego, porównując go z wielkimi stylistami tego czasu — Górnickim, Orzechowskim, Skargą, Wujkiem. Janusz Pelc, oceniając styl Wróżek, pisze: „Proza Kochanowskiego jest mniej ozdobna, mniej emfatyczna i mniej wyrobiona także" (Pelc 1987: 467).

Obrony Kochanowskiego jako autora piszącego również prozą podjął się Maciej Włodarski - w artykule $O$ stylu prozy Jana Kochanowskiego zestawił jego utwory z podobnymi dziełami innych autorów współczesnych poecie, np. Wróżki z Ziemianinem albo Rozmowa ojca z synem J.D. Solikowskiego, Wyktad cnoty, Iz pijaństwo, O Czechu i Lechu z Do uczciwego a bacznego Polaka - traktatem moralistycznym ze Zwierciadta M. Reja, Wzór pań mężnych z historią o Kammie z Dworzanina polskiego Ł. Górnickiego (Włodarski 1987: 111-121). Porównując budowę okresu i zdania oraz użycie środków retorycznych, autor zauważa, podobnie jak inni badacze, że styl Kochanowskiego jest mniej ozdobny, jednak przeprowadzona analiza podaje w wątpliwość stwierdzenie, że pisarz ustępuje innym w precyzji w budowaniu okresu. To, co według innych badaczy świadczy „o słabej ekspresji lub też nieporadności tejże prozy”, zdaniem Włodarskiego, wręcz przeciwnie, jest dowodem kunsztu, „odnosimy więc wrażenie, że Kochanowskiemu bardziej niż na ozdobności stylu zależało na jasności wypowiedzi, na celnym i stosunkowo prostym ujmowaniu wypowiadanych myśli" (Włodarski 1987: 115-116). Jasność i precyzja w formułowaniu i wyrażaniu myśli, dokładne wyważenie słów, oszczędne, ale trafne wykorzystanie środków stylistycznych to według Włodarskiego podstawowe cechy prozy Kochanowskiego, świadczące o tym, że ,Jest to bez wątpienia proza kunsztowna, stojąca na wysokim poziomie artystycznym". Włodarski zgadza się z tym, że w porównaniu z twórczością poetycką teksty prozaiczne nie są tak doskonałe. Wynika to przede wszystkim 
z rodzaju tych tekstów, albowiem wymagania stawiane tekstom poetyckim i prozatorskim są różne. Natomiast porównanie utworów jednorodnych gatunkowo, tzn. prozy poety czarnoleskiego z twórczością prozatorską innych autorów, prowadzi do wniosku, że ,pod względem sprawności konstrukcyjnej oraz jasności wysłowienia proza mistrza czarnoleskiego nie ustępuje dokonaniom literackim wybitnych nawet stylistów" (Włodarski 1987: 121). Dla piszących głównie prozą, dla kaznodziei była to podstawowa forma wypowiedzi, dla poety zaś formą podstawową był tekst wierszowany, mimo to artyzm jego prozy nie jest mniejszy.

W niniejszym szkicu postaram się pokazać i opisać środki perswazji użyte przez poetę $\mathrm{w}$ jego tekstach prozatorskich, pomijając listy jako specyficzny gatunek tekstu. Perswazję traktuję jako kategorię retoryczną służącą przekonywaniu (por. Sławkowa 1994: 97). Jak pisze Marek Tokarz, słowo „perswazja” w dzisiejszym, technicznym znaczeniu rozpowszechniło się około pół wieku temu. Wcześniej jego funkcję pełniło słowo „retoryka”, rozumiane jako „dar słowa i sztuka wywierania wpływu na słuchaczy" (Tokarz 2006: 219). Można się zastanawiać, czy warto zajmować się środkami perswazji w tekstach niepublikowanych za życia twórcy, skoro nie znamy odbiorcy tych tekstów, nie wiemy, do kogo były rzeczywiście adresowane. Jednakże każdy z tych tekstów jest kierowany do założonego przez autora odbiorcy i każdy ma swój cel.

Potrzebę badań dotyczących prozy renesansowej podkreślała już Anna Wierzbicka w monografii System sktadniowo-stylistyczny prozy polskiego renesansu. Autorka zwróciła uwagę między innymi na „,doniosłą rolę retoryki w całym renesansowym modelu kultury” i ,głęboko zakorzenione u ludzi Renesansu, przejęte od starożytnych przekonanie o odrębności problematyki stylistycznej prozy i o potrzebie jej artystycznego kształtowania" (Wierzbicka 1966: 7). W swojej pracy skupiła się przede wszystkim na składni i tendencjach stylistycznych w szesnastowiecznej prozie retorycznej. O środkach perswazji retorycznej w Satyrze utworze poetycko-publicystycznym wydanym za życia (1564) Kochanowskiego — pisała Ewa Sławkowa (1994: 97), motywując to tym, że kategoria perswazji znajduje się „w centrum zainteresowania retoryki - wyrosłej z metodycznego opisu naturalnej dążności ludzkiej mowy do przekonywania innych". Sławkowa omawia szczegółowo kompozycję. Stwierdza, że w analizowanym przez nią utworze „występuje apostrofa, bezpośredni zwrot do adresata kierowany przez mówcę, w funkcji moralizatorskiej przestrogi" (Sławkowa 1994: 98). Autorka wymienia także inne środki perswazyjne, takie jak: dominujące wypowiedzi imperatywne w 2. osobie liczby pojedynczej, zdania z trzeba, tzw. powinnościowe, zdania dyrektywne oraz pytania retoryczne (Sławkowa 1994: 99).

Wymienione na wstępie utwory prozatorskie poety są zróżnicowane pod różnymi względami: gatunku, formy, długości i celu wypowiedzi. Już sam dobór gatunków tekstu do tematyki świadczy o tym, że tekst miał pełnić funkcję perswazyjną. Najdłuższy utwór, Wróżki, należy do publicystyki społeczno-politycznej, powstał prawdopodobnie po sejmie egzekucyjnym (nie wcześniej niż po 1564 
roku), poprzedzony jest wierszem skierowanym do Mikołaja Firleja, wojewody lubelskiego: Nie frasuj sobie Mikołaju głowy. Sam wywód, liczący 23 strony, ma formę dialogu Plebana z Ziemianinem. Rozmowę rozpoczyna replika-bodziec wypowiadana przez Ziemianina, jest ona nawiązaniem do sytuacji przedstawionej w Pieśni wstępnej: Co to jest ks(ięże) Plebanie, że tak barzo, źle tuszycie rzeczypospolitej naszej? Nie jest to jednak rozmowa polegająca na równorzędnej wymianie zdań i myśli, nie następuje tu bezpośrednia wymiana ról nadawczo-odbiorczych. W replikach-reakcjach ${ }^{3}$ Plebana jest uzasadnianie złych przewidywań, informuje on o niebezpieczeństwie, jakie zagraża Rzeczypospolitej, i wskazuje przyczyny tego stanu. Jego repliki są o wiele dłuższe, można powiedzieć, że na poziomie tekstowym jest to monolog Plebana przerywany krótkimi replikami Ziemianina, które służą podtrzymaniu kontaktu, są wyrazem zainteresowania ze strony odbiorcy. Jest to dialog na poziomie interakcyjnym, dopiero na końcu repliki obydwu interlokutorów są krótsze i następują szybkie zmiany ról. Swobodna forma dialogu pozwala na częste posługiwanie się cytatami i powoływanie się na autorytety. Najczęściej poeta ustami Plebana odnosi się do Cycerona, autora dzieła De republica, są też przywoływani Filip Macedoński oraz inni mówcy, filozofowie, pisarze i poeci. Ilustracji problemów Rzeczypospolitej i sposobów ich rozwiązania służą przykłady z historii starożytnej, np. odwołanie się do Cycerona, Homera i Platona:

[...] nie omylił się i Cycero na tym tusząc, że ten upadek starych obyczajów miał za sobą i rzeczpospolitą potargnąć, bo jeszcze za jego wieku za tym starych obyczjów wzgardzeniem przyszli w roztyrk Rzymianie, w którym jako wiele ludzi między sobą potracili, strach słuchać. Na koniec pod tyranna wpadli [...] (Kochanowski 1997: 162, 165).

Jest wierszyk jeden u Homera, którego ten sens pamiętam: „Źle, gdzie ich wiele rządzi; jeden król niechaj będzie" (Kochanowski 1997: 182).

A na to zezwolisz mi, co gdzieś Plato mówi, że za odmianą muzyki i rzeczpospolita odmienić się musi? ... Na to sie wszyscy filozofowie starzy zgadzali, że muzyka ma moc nad umysły ludzkiemi [...] (Kochanowski 1997: 182, 185).

Jak pisze Sławkowa (1994: 100), „Obecność wypowiedzi perswazyjnych odnoszących się do czasu przeszłego, które doradzają lub zachęcają (łac. suasio) albo odradzają lub zniechęcają (łac. dissuasio) do jakiegoś problemu", jest charakterystyczna dla retorycznego gatunku doradczego. Tworząc tekst, Kochanowski używał zdań wtrąconych, wprowadzał przytoczenia, pytania retoryczne i sentencje łacińskie, które były środkami służącymi wzmocnieniu argumentacji. Tekst Wróżek zbudowany jest z krótkich zdań (na 170 fraz tylko 20 szerzej rozbudowanych i 10 długich skomplikowanych okresów, por. Włodarski 1987: 112). Wynika to zapewne z wybranej formy wypowiedzi, teksty dialogowe na ogół cha-

3 O jednostkach tekstów dialogowych zob. Data 2011: 61-93. 
rakteryzuje nieskomplikowana składnia z przewagą zdań parataktycznych. Zastosowanie formy dialogowej, jako bliższej zwykłym użytkownikom języka, mogło pomóc w uzyskaniu zamierzonego celu perswazyjnego, czyli przekonaniu odbiorcy o powadze sytuacji, o zagrożeniu, o niebezpieczeństwach wiszących nad Rzecząpospolitą i o konieczności podjęcia działań, które zapobiegną nieszczęściu.

Z kolei Wzór pań mężnych to traktat moralistyczny oparty na Plutarchu, składający się z sześciu portretów zacnych niewiast. Celem autora było pokazanie męstwa i siły kobiet, podkreślenie takich wartości, jak cnota i uczciwość, a zarazem wskazanie wzorów (por. tytuł) godnych naśladowania. Aby osiągnąć ten cel, autor posługuje się opisem, przedstawia tylko fakty z życia bohaterek, nie komentując ich. Interpretację pozostawia odbiorcy, co także pomaga osiągnąć zamierzony cel. Jak pisze Korolko, uczciwość, cnota i męstwo to ideały, których obronie miała służyć retoryka (Korolko 1990: 35) i to zadanie Kochanowski tu realizuje, przedstawiając odpowiednie wzory zachowań.

Również kolejne teksty - K temu o cnocie i O sprosności pijaństwa - są traktatami moralistycznymi mającymi służyć wyżej wymienionym celom, a ponadto przekonać odbiorcę do cnoty trzeźwości. Badacze Kochanowskiego uważają te teksty za niedokończone, ponieważ kompozycyjnie brak im zakończenia, puenty, być może jest to chwyt zastosowany przez autora celowo, aby odbiorca mógł sam wyciągnąć wnioski. Mimo braku zakończenia teksty stanowią spójną całość. Traktat o cnocie, w niektórych wydaniach zatytułowany jako Wykład (inaczej objaśnienie) cnoty, realizuje schemat kompozycyjny wykładu. Budowa tekstu jest bardzo przejrzysta, luźne na pozór refleksje są przedstawiane w uporządkowany sposób. Tekst rozpoczyna zdanie:

Cnotę i w nieprzyjacielu, i w nieznajomych miłujemy. Ale to słowo cnota wiele w sobie zamyka. Naprzód mądrość [...] Potym sprawiedliwość [...], Trzecia wielkość umysłu [...], Czwarta skromność [...] (Kochanowski 1997: 215).

Utwór sprawia wrażenie lekkiego, zdania są krótkie, często występują równoważniki zdań. Największy okres ma 10 członów i jest zbudowany z 8 związków podrzędnych i ma 4 ,piętra” (por. Włodarski 1987: 114). Pojawiają się porównania: z czterech cnót jako z czterech studzien; ale jako złota w ogniu tak przyjaciela w potrzebie doświadczamy; równie jako i cień / kiedy słońce za chmurę zajdzie, pytania retoryczne, np. Herkules co czynit, aby byt milowan?, wtrącenia metatekstowe - tak jako się powiedziało; a jako Grekowie mówia / po oltarz. Użyte środki mogą świadczyć o tym, że w zamyśle autora tekst był skierowany do mniej wyrobionego adresata.

Podobnie jest w przypadku drugiego traktatu - Iz pijaństwo jest rzecz sprosna a nieprzystojna człowiekowi. Po tym tekście zamieszczone zostały trzy fraszki związane tematycznie z traktatem i ośmieszające wadę, nałóg, jakim jest pijaństwo: Źle dopijać się przyjaciela, Petna prze zdrowie, Przymówka chłopska. 
Dodanie właśnie w tym miejscu krótkich i lekkich utworów służy także celom perswazyjnym, ma dodatkowo wzmocnić argumentację i perswazję.

O Czechu i Lechu historyja naganiona to poprzedzony wierszem Omen traktat historyczny. Wiersz pełni tu funkcję wprowadzenia w tematykę rozprawy: Gdzie poźrze, wszędy widze polskiej sity znaki:| Tu do Czarnego Morza ... Tu droga ... przez śnieżne Batchany,| Tu Psie Pola, ... brzeg pruski ... Bo od Zmarzłego Morza po brzeg adryjański| Wszystko byt opanowat cny naród stowiański.|(Kochanowski 1997: 201).

Autor krytykuje współczesne mu poglądy na temat pochodzenia narodów słowiańskich, zbijając ich argumentację własnymi wnioskami. Już na wstępie zarzuca niesłuszność dowodzenia naszych początków baśniami, twierdząc, że nie ma dowodów na istnienie Lecha i Czecha. Sposób kształtowania wypowiedzi jest tu nieco inny, traktat ma formę spójnego wykładu historycznego, dlatego pojawiają się dłuższe zdania, więcej zdań złożonych podrzędnie, podobnie jak w opisanym wyżej utworze są tu wtrącenia, ale jest ich znacznie więcej, np. ani Kadtubski ... w swej historyjej/żadnej o nich / ile pomnieć mogę/wzmianki nie czyni; jakom wysszej powiedzial; jako oni zowa; iż tak mam rzec. Porównania, paralelizm, synonimy i wyliczenia sprawiają , że styl tych utworów jest stylem obrazowym" (Włodarski 1987: 114).

Przy pogrzebie rzecz to krótka mowa pogrzebowa ku czci zmarłego brata poety Kaspra. Również ten tekst charakteryzuje prostota stylu - autor w prosty, niewyszukany sposób podnosi zasługi zmarłego, mimo to mowa jest ciekawa i dobrze skonstruowana pod względem retorycznym i stylistycznym.

Analizując prozę Kochanowskiego, nie można pominąc Apoftegmatów. Według definicji zamieszczonej w Słowniku polszczyzny Jana Kochanowskiego są to „krótkie dowcipne anegdoty i opowiadania o znanych ludziach, cechach ich charakteru, także o zdarzeniach" (Kucała (red.): 1994-2012). Włodarski używa na ich określenie terminu „facecja”. Uważa on, że Apoftegmata to dzieło dopracowane i zgrabne stylistycznie, mające własną wartość artystyczną. Utwór ten był niedoceniany przez badaczy, którzy skłaniali się do uznania go jedynie za notatki, na podstawie których miały powstać fraszki. Kochanowski wprowadził do Apoftegmatów konstrukcje z języka mówionego, zgadzam się tutaj z Włodarskim (1987: 120), że był to świadomy zabieg stylistyczny, a także, moim zdaniem, retoryczny. O takich zabiegach podobnie sądzi Wilkoń, który pisze, że opinie badaczy, zarówno literatów, jak i językoznawców, o potoczności tekstów Kochanowski są nieporozumieniem (Wilkoń 2004: 50).

Jeśli idzie o budowę składniową, to w tekstach poety czarnoleskiego zdania często są rozpoczynane spójnikami, spójniki nie tylko łączą składniki w zdaniu i zdania złożone, lecz także są wyznacznikami spójności jednostek większych niż zdanie i stoją wtedy na początku frazy, pełniąc funkcję nawiązującą ${ }^{4}$ Porównaj-

4 O funkcjach spójników zob. Data 1999. 
my frekwencję spójników w poszczególnych utworach w kolejności $\boldsymbol{a}, \boldsymbol{a l e}, \boldsymbol{i}-$ pierwsza wartość oznacza liczbę wystąpień w funkcji nawiązującej, a druga liczbę spójników: Wr: 28/92, 14/44, 5/160; Wzór: 17/21, 2/4, 3/49; Cn: 2/18, 8/10, 0/13; Pij: 4/22, 4/15, 4/24; Czech 2/12, 2/7, 0/48; Pog 6/10, 1/14, 3/40; Ap 5/26, $0 / 0,5 / 22$. Kochanowski często stosuje zdania wtrącone, przytoczenia, pytania retoryczne, które służą wzmocnieniu, podparciu sądów autora i przekonaniu odbiorcy. Na podstawie analizy omawianych tekstów można stwierdzić, że funkcja perswazyjna jest w nich realizowana na różnych poziomach:

- wyboru formy wypowiedzi (dialog, monolog);

- wyboru gatunku tekstu (traktat, wykład, opowiadanie);

— doboru środków stylistycznych wzmacniających perswazję;

— doboru środków budowy tekstu (nawiązania między zdaniowe, budowa okresu i zdania);

— doboru leksykalnego (słownictwo służące wartościowaniu, nazwy wartości).

Bogdan Walczak na podstawie analizy porównawczej środków perswazyjnych zastosowanych w wybranych tekstach kazań staropolskich i środków stosowanych we współczesnej homiletyce stwierdził, że językowe środki perswazji, takie jak leksyka wartościująca i dyrektywna, zdania celowe, pytania retoryczne, definicje perswazyjne, nie są w retoryce nowością, ponieważ większość elementów perswazyjnych wyróżnianych we współczesnych kazaniach używana była już w XIV i XV wieku (Walczak 2003).

W okresie odrodzenia retoryka stanowiła podstawę wykształcenia humanistycznego (szczególnie na włoskich uniwersytetach), ponieważ uważano, że „Rzetelnie uprawiana retoryka, [...] uczy trudnej sztuki rządzenia, buduje humanistyczną kulturę, jest mistrzynią życia moralnego" (Korolko 1990: 185). Doceniano też wagę sztuki przemawiania, odnoszono się do retoryki starożytnej, a według Tacyta „ten jest mówcą, kto potrafi o każdej kwestii mówić w sposób piękny, ozdobny i przekonywający — odpowiednio do godności sprawy, wyzyskując okoliczności, budząc zachwyt w słuchaczach" (za: Korolko 1990: 39). Kochanowski spełnił te wymagania, wybierając tematykę, słownictwo i środki stylistyczne, dobierając odpowiednią do tematu i adresata formę swoich wypowiedzi, nadając im ozdobny stosownie do formy i celu kształt, prowadząc przekonująco argumentację. Pisał, wybierając styl zgodnie z obowiązującymi zasadami: styl prosty/niski do celów dydaktycznych, średni/umiarkowany służący pochwale, naganie (mowy patriotyczne, okolicznościowe, religijne), wysoki/wzniosły dla spraw o wielkiej wadze (środki emocjonalne mające pobudzać do wielkich czynów i wzniosłych działań). „Retoryka jako teoria sztuki słowa perswazyjnego służyła przede wszystkim »literaturze faktu«, literaturze parenetycznej, dydaktycznej w najlepszym sensie tego określenia; patronowała upowszechnianiu wiedzy i treści politycznych, społecznych i religijnych" (Korolko 1990: 19). Jak stwierdza Korolko, pisarz renesansowy miał być duchowym przewodnikiem społeczeństwa, 
jego doradcą, piewcą cnoty, czynów i postaw służących „pospolitej rzeczy”, takie były bowiem założenia renesansowej doktryny retorycznej. Zdaniem badacza Kochanowski, wykształcony we Włoszech, także te wymagania zrealizował (Korolko 1991: 52). Zwraca on również uwagę na fakt, że twórczość Kochanowskiego była wykorzystywana później do różnorodnych celów retoryczno-perswazyjnych i jest wykorzystywana do dziś. Świadczy to o tym, że Jan z Czarnolasu był retorem i poetą w jednej osobie, potwierdza to opinia i praktyka jego naśladowców.

Sumując powyższe rozważania, można stwierdzić, że poeta Jan Kochanowski na pewno miał dar słowa. W jakim stopniu opanował sztukę wywierania wpływu na słuchaczy, czyli cechy charakterystyczne dla retoryki obecnie określanej perswazją ${ }^{5}$, trudno określić z tak odległej perspektywy czasowej. Na podstawie analizy jego tekstów prozatorskich z całą pewnością możemy powiedzieć, że miał umiejętność odpowiedniego stosowania środków i zabiegów retorycznych służących przekonywaniu odbiorcy.

\section{Źródła}

Kochanowski J. (1997), Proza, [w:] Dzieła wszystkie, wydanie sejmowe, t. 7, cz. 2, oprac. B. Kreja, B. Otwinowska, M. Szymański, Wrocław, s. 122-237.

Kucała M. (red.) (1994-2012), Słownik polszczyzny Jana Kochanowskiego, t. 1-5. A-Ż, wraz z indeksem a tergo, Kraków.

\section{Bibliografia}

Data K. (1999), I jako wyznacznik organizacji tekstu w piśmiennictwie XVI wieku, [w:] Język - teoria - dydaktyka, red. B. Greszczuk, materiały 21. konferencji językoznawczej, zorganizowanej w Trzcinicy k. Jasła, w dniach 27-29 maja 1998 roku, Rzeszów, s. 45-50.

Data K. (2011), Struktura dialogu we współczesnej polszczyźnie mówionej, Kraków.

Data K. (2015), Oralność tekstów Jana Kochanowskiego, „Quaestiones Oralitatis” I 2, s. 85-99.

Korolko M. (1990), Sztuka retoryki. Przewodnik encyklopedyczny, Warszawa.

Korolko M. (1991), Jan Kochanowski i jego twórczość jako retoryczne narzędzia publicystyki polskiej w latach 1584-1625, [w:] Jan Kochanowski w czterechsetlecie śmierci, red. S. Nieznanowski, J. Święcha, Lublin, s. 41-52.

Pelc J. (1987), Jan Kochanowski. Szczyt renesansu w kulturze polskiej, Warszawa.

Sławkowa E. (1994), Środki retorycznej perswazji w satyrze Jana Kochanowskiego, „Prace Językoznawcze, nr 22. Studia Historycznojęzykowe. Prace Naukowe Uniwersytetu Śląskiego”, nr 1410.

Tokarz M. (2006), Argumentacja, perswazja, manipulacja, Gdańsk.

Walczak B. (2003), Perswazja językowa - prolegomena historyczne, [w:] Język perswazji publicz$n e j$, red. K. Mosiołek- Kłosińska, T. Zgółka, Poznań, s. 52-56.

Wierzbicka A. (1966), System składniowo-stylistyczny prozy polskiego renesansu („Historia i Teoria Literatury. Studia"), Warszawa.

5 Tu nawiązuję do rozważań Tokarza o retoryce i perswazji — zob. (Tokarz 2006: 192). 
Wilkoń A. (2004), Dzieje języka artystycznego w Polsce. Renesans, Katowice.

Włodarski M. (1987), O stylu prozy Jana Kochanowskiego, „Rocznik Komisji Historycznoliterackiej” 24, s. 11-121.

Ziomek J. (1973), Renesans, Warszawa.

\section{Persuasion in Jan Kochanowski's prose}

\section{Summary}

In this article we will review persuasive language devices used in Jan Kochanowski's prose texts that vary in terms of text genres, forms, length and purpose of expression. All the discussed works of the poet belong to different text genres, such as: social and political journalism, moralist treatise, historical treatise, funeral speech, short witty anecdotes and stories.

The text analysis proves that there are often conjunctions at the beginning of many sentences. These words not only link sentence components or complex sentences but they also determine the cohesion of larger units than sentences and mark a referential function. Kochanowski often incorporates parentheses, citing and rhetorical questions. As a result, a persuasive function is achieved due to the choice of an utterance form and a text genre, appropriate selection of stylistic devices enhancing persuasion and text construction forms and, last but not least, adequate lexical diversity. In his style Kochanowski followed the rules of rhetoric characteristic of the 16th century. The low/plain style had a didactic purpose, the middle style was chosen to praise or to reprimand others and the high/grand style was limited to texts referring to matters of great importance.

Keywords: prose, persuasive language devices, text genres, syntax 